DOI 10.14746/ssp.2018.1.3

\author{
Adam R. BARTNICKI \\ Uniwersytet w Białymstoku
}

\title{
Borys Jelcyn jako przywódca polityczny
}

Streszczenie: Borys Jelcyn bardzo sprawnie doprowadził do rozwiązania ZSRR i zmonopolizowania władzy, nie był jednak mentalnie przygotowany do tego, by być przywódcą narodu w okresie transformacji lat 90 . W jego działaniach nie widać było zamiaru umocnienia, konsolidacji państwa, a jedynie chęć umocnienia własnego przywództwa. Budowany przez niego system władzy stał się fundamentem, na którym powstał reżim autorytarny Władimira Putina. To właśnie Jelcyn nauczył rosyjskie elity, jak naginać, a nawet omijać procedury demokratyczne jak lekceważyć i marginalizować opozycję, zawłaszczać środki masowej informacji i korumpować dziennikarzy; jak ubezwłasnowolnić polityków i inteligencję; jak odsuwać społeczeństwo od wpływu na życie polityczne; w jaki sposób życie to dezintegrować i lekceważyć, wywołał społeczną tęsknotę za stabilizacją i rządami ,silnej ręki”, zniechęcił Rosjan do demokracji i wolnego rynku, umożliwił powstanie rosyjskiego „oligarchizmu”, przywrócił Rosji stare sowieckie postrzeganie rzeczywistości międzynarodowej, na nowo zalegalizował przemoc państwową. Jelcyn zwalczał komunizm, ale tak naprawdę nie chodziło tu o ideologię, tylko o ludzi, którzy stali na jego drodze. Wiele elementów państwa sowieckiego z rozmysłem zresztą przejął. W ten sposób doszło do swoistej transpozycji komunizmu. Jego część imperialną, społeczną i tę dotyczącą władzy politycznej zaadaptowano do idei nowej Rosji. Jelcyn miał niewątpliwe zasługi w tworzeniu się niepodległej Rosji, cała sfera wolności była już jednak tylko aktywnym rozwinięciem przemian zapoczątkowanych przez Michaiła Gorbaczowa.

Słowa kluczowe: Rosja, Jelcyn, komunizm, demokratyzacja, postkomunizm

B orys Jelcyn pod koniec lat 80. stał się przywódcą ruchu demokratycznego (i niepodległościowego), mając minimalne zasoby, ale bardzo silną motywację. W tym zakresie jego cele były często zbieżne z motywacjami jego zwolenników, z tym że to nie Jelcyn określał ich kierunek, raczej aktywnie wykorzystywał oczekiwania innych, kierując je na rozwiązania i cele własne. Nawet jeśli jego przywództwo było w dużym stopniu wynikiem nieoczekiwanego splotu okoliczności historycznych i politycznych, które nie zawsze kontrolował, to niemal zawsze potrafił odnaleźć się w nurcie zmian. Zasługą Jelcyna było też to, że potrafił je 
maksymalnie wykorzystywać. Czasem kreował sytuacje, które wyglądając na przypadkowe, przypadkowymi nie były. Miał cechy, pozwalające mu zaistnieć na politycznym firmamencie - i co więcej - utrzymać się na nim. Ostatecznie doszedł do władzy, używając na przemian retoryki (i działań) rewolucyjnej zmiany i istotnych zaniechań hamujących owe zmiany. Ostatecznie pozostawił Rosję w głębokim kryzysie chociaż przez całą dekadę próbował ją reformować.

Jelcyn nie był przygotowany na skalę problemów, z którymi przyszło mu się zmierzyć, brakowało mu doświadczenia, ale też wiedzy. Przypominał trochę „kacyka”, który przypadkowo znalazłszy się na szczycie robił wszystko żeby na nim pozostać. Nie potrafił jednak rządzić, godzić interesów różnych środowisk, być prawdziwym przywódcą. Nie rozumiał, że interes państwa nie musi być tożsamy z jego oczekiwaniami. Co gorsze, przyzwyczajenia wyniesione z pracy w aparacie komunistycznym powodowały, że nie tolerował wokół siebie ludzi, którzy w jakikolwiek sposób mogli zagrozić jego pozycji. Skutek takich działań był aż nadto widoczny - Rosja Jelcyna została pozbawiona wybitnych indywidualności politycznych. Ostatecznie zabrakło nie tylko możliwości i woli, ale też ludzi, którzy potrafiliby pchnąć państwo w stronę skutecznych reform i demokracji. W znakomity sposób ułatwiło to działania elitom wywodzącym się z KGB. Jelcyn nie był jednak reformatorem - szedł tropem przemian rozpoczętych przez Michaiła Gorbaczowa, ale nie wniósł do nich wiele nowego („terapia szokowa" w gospodarce to radykalizm metod, ale nie zmiana celów). Podstawowym lekarstwem na dolegliwości trapiące Rosję stawały się nie reformy, ale przetasowania kadrowe. Miejsce „demokratów” zajmowali „siłownicy”, tych następnie zastępowali „liberałowie”, po czym znów wracano do „siłowników”. W połowie lat 90. XX w. Kreml stał się centrum grawitacji lobbystów. Przedstawiciele biznesu i finansjery uświadomili sobie ogromną szansę, jaką dawała możliwość wpływania na władzę. Prezydent był zmuszony manewrować pomiędzy wpływowymi grupami (finansowo-przemysłowymi, regionalnymi, biurokratycznymi itd.). Obrana przez niego taktyka polegała nie na przyjęciu na siebie roli stabilizatora systemu, czyli na tłumieniu wybuchających konfliktów, lecz przeciwnie - na wywoływaniu napięć i zachęcaniu do sporów, które musiały kończyć się jego politycznym arbitrażem.

Celem niniejszej analizy jest pokazanie jak Borys Jelcyn wpływał na kształt, kierunek i zakres przemian w Rosji, jak wyglądał system jego władzy i jakie rodziło to konsekwencje. 


\section{Polityczna osobowość Borysa Jelcyna}

Borys Jelcyn nie miał przekonań, miał tylko ideę władzy - mówił znany działacz społeczno-polityczny Władimir Pribyłowski (Прибыловский, 2009). Prawdziwa żądza władzy - chęć „wdrapania się tak wysoko, jak tylko się da" - uwypukliła się w Jelcynie po usunięciu z politbiura w 1987 roku. Wstrząs, strach przed utratą wszystkiego, co osiagnął, ujawnił istotną cechę jego natury - walczył z pełną determinacją dopiero wtedy, kiedy był bliski klęski, kiedy jego władza była kwestionowana lub zagrożona, kiedy pojawiali się potencjalni pretendenci do wyrugowania go z Kremla - wtedy ożywał, stawał do walki, z pasją, uporem i konsekwencją, niszczył przeciwników, przeszkody, a także, jego zdaniem, niezbyt oddanych przyjaciół. Po zwycięstwie zastygał w letargu. Osiągał spokój, do którego stale dążył, jednak stan ten nie był uwarunkowany sukcesami, zrealizowanymi celami itd., tylko chwilowym brakiem konkurentów do władzy. Jelcyn nigdy nie wykazał dość determinacji, by bronić reform, bronić Gajdara, Kirijenki, Kozyriewa. Bez wahania poświęcał ich w imię doraźnych korzyści politycznych. Jego jedynym prawdziwym sukcesem było doprowadzenie do rozwiązania ZSRR, ale tu rzecz szła o samodzielność Rosji, a więc de facto samodzielną władzę. Gawriłła Popow pisał, że władza stanowiła dla prezydenta największą wartość, której nie zamieniłby na nic. Nie istniało dla niego życie bez władzy. W tym aspekcie Popow psychologicznie porównywał Jelcyna ze Stalinem (Попов, 1998, s. 189). Jelcyn odnosił w tej walce sukcesy, jednak pogrążały one państwo - ciągła gotowość do starcia destabilizowała sytuację w kraju, sprzeczne interesy prowadziły do rozregulowania mechanizmów politycznych. Zaskakujące posunięcia kadrowe Jelcyna, demonstrującego w ten sposób swą dominację, jeszcze bardziej zaogniały sytuację. Prezydent nie pozostawiał w tej kwestii niejasności. Wszystko rozgrywało się w systemie 0/1 - ,przyjaciel"-,,wróg” - z tym, że nawet jego bliscy, nawet najwierniejsi z wiernych, bez problemu mogli znaleźć się w tej drugiej kategorii. Gorbaczow mówił: „w Jelcynie było zawsze coś takiego, coś w środku, może hardość, może nawet mściwość i pod tym względem się nie zmienił. Ten człowiek niczego nie wybacza" (Remnick, 1997, s, 28). Rzeczywiście, wydaje się, że był bardzo pamiętliwy, czuły na punkcje swojej dominacji - dosłownie nad wszystkimi i nad wszystkim. Należał do typu ludzi, którym należało zawsze schlebiać i z nimi przegrywać, w przeciwnym razie niemal automatycznie można było stać się wrogiem. Jakakolwiek rywalizacja, nawet podejrzenie o chęć przyćmienia splendoru czy władzy, kończyła 
się polityczną śmiercią. Zwyczajną zazdrością można było tłumaczyć wiele posunięć kadrowych prezydenta. W konsekwencji chorowało państwo, gospodarka i rosyjska demokracja. Jelcyn posiadał jednak jeszcze inną, istotną cechę, która prawdopodobnie pozwoliła mu utrzymać się na szczycie - nie był brutalny, nikt nie musiał obawiać się o swoje bezpieczeństwo osobiste czy majątek. Był przy tym przewidywalny, wiadomo było jak się zachowa, jak do niego dotrzeć, odtwarzał środowisko, w którym elity potrafiły się poruszać. Dawał gwarancję pewnej stabilizacji, tej zaś nie mogli dać jego potencjalni konkurenci.

Kim tak naprawdę był Borys Jelcyn? Wskazującym nowe horyzonty, nie do końca rozumianym wizjonerem, czy tylko politycznym karierowiczem, który poprzez dekompozycję i negację ZSRR pragnął zaistnieć na scenie politycznej? Kreatorem wydarzeń, rewolucjonistą realizującym własne wizje czy konformistą płynącym z nurtem dziejów? Naiwnym idealistą czy wyrachowanym graczem? Pewnym siebie, władczym „carem” czy pełnym kompleksów aparatczykiem z prowincji? Chorym człowiekiem z problemami alkoholowymi czy dynamicznym politykiem bezwzględnie prącym do władzy? Reformatorem czy burzycielem? Motorem zmian czy ich hamulcem? Istnieje pokusa, aby opisać go za pomocą jakiegoś prostego klucza, dwubiegunowego schematu. Jeżeli przyjrzeć się faktom z jego politycznego życia, sprawa staje się nader skomplikowana. Prawdopodobnie wszystkie kontrastowe oceny są prawdziwe. Jelcyn był człowiekiem zagmatwanym, rozdartym wewnętrznymi sprzecznościami (Колтон, 2013, s. 8). Co więcej, w jego przypadku można mówić o kilku zupełnie różnych wcieleniach. Zmieniał się. W połowie lat 80 . był zupełnie innym politykiem niż w latach 1991-1993; jeszcze inny Jelcyn rządził Rosją w latach 1996-1999. Był człowiekiem o wielu obliczach i zmiennym usposobieniu. Jego charakter i nastroje pozostawały zagadką nawet dla najbliższego otoczenia. Jelcyn był też dobrym aktorem, zręcznie dobierającym kolejne maski. Nie ma pewności, która z jego twarzy była prawdziwa. Trudno też do końca odgadnąć, jakie elementy decydowały o trwaniu przywództwa Jelcyna instytucjonalne, charyzmatyczne, polityczne? $\mathrm{Z}$ pewnością konfiguracja poszczególnych czynników ulegała zmianom w czasie jego prezydentury.

Mówiono, że nie miał żadnego programu, poza jednym - walką o władzę. Z pewnością było w tym wiele prawdy. Jelcyn niewątpliwie przeszedł olbrzymią ewolucję: od szefa prowincjonalnego aparatu partyjnego w Swierdłowsku - do przywódcy ruchu demokratycznego. Zmiana 
ta nigdy nie była jednak całkowita. System komunistyczny (i to właśnie w prowincjonalnym wydaniu) wywarł głęboki i niezatarty ślad w jego mentalności, postrzeganiu świata, organizacji własnego otoczenia, metodach pracy, sposobie i formie relacji z podwładnymi. Jelcyn był wytworem sowieckiej nomenklatury, w takim systemie wyrastał i mniej lub bardziej świadomie odtwarzał jego realia. System władzy w czasach Jelcyna odwzorowywał więc komunistyczny schemat zależności, powiązań, a także sposób uprawiania polityki, którego istotą była skłonność do intryg, a warunkiem sukcesu - możliwość zbliżenia się do lidera, i umiejętność wpływania na jego decyzje.

Jelcyn nie miał zahamowań natury ideologicznej, nie przywiązywał się do idei, zadań, współpracowników. Potrafił z wyrachowaniem zmieniać zdanie. Gdyby w latach 1987-1990 Gorbaczow miast walczyć z nim, włączył go jako ważne ogniwo do swojej ekipy, Jelcyn stałby się zapewne zagorzałym obrońcą ZSRR i genseka. Trudno było dostrzec, co jest rzeczywiście dla niego ważne. Gubił się w określaniu priorytetów i propagandowych haseł. Nikt nie wiedział, co tak naprawdę dla niego znaczą słowa: „demokracja”, „wolny rynek”, „rządy prawa”, „reformy gospodarcze", ,interes narodowy”. W jego ustach brzmiały one zresztą jak bezmyślne frazesy. Był niekompetentny, nie rozumiał gospodarki, demokracji, polityki międzynarodowej, dyplomacji. Często popełniał gafy, wyszydzane potem w komentarzach, zarówno w kraju, jak i za granica. Podejmował niezrozumiałe decyzje, wygłaszał przemówienia, z których trzeba było go tłumaczyć, zachowywał się w sposób budzący zażenowanie otoczenia oraz całego społeczeństwa. Intuicja często zastępowała mu logiczne myślenie. Nigdy nie wiadomo, co jest w nim autentyczne, a co inscenizowane i udawane. Potrafił kłamać (Третьяков, 2000), konfabulować, zrzucać odpowiedzialność na swoich bliskich. Był konfliktowy, obrażalski (Remnick, 1997, s. 27) i małostkowy, a przez to mało konkretny w celach, które stawiał przed Rosją. Ambitny, często pozbawiony skrupułów, chorobliwie żądny władzy, nieprzewidywalny (Попов, 1998, s. 189) ${ }^{1}$, gwałtowny, zazdrosny ${ }^{2}$. Nie był jednak mściwy. Umiał też być asertywny, czarujący, uwodził rosyjskich intelektualistów, największych

${ }^{1}$ Popow pisał, że był nieprzewidywalny tylko dla obcych. Jego najbliżsi zawsze wiedzieli jak postapi.

${ }^{2}$ Wiele ocen wystawianych obecnie przez autsajderów lat 90. - ludzi odsuniętych, upokorzonych, pominiętych przez Jelcyna - z pewnością nacechowanych jest negatywnymi emocjami, dlatego też należy podchodzić do nich krytycznie, z odpowiednim dystan-sem. 
przywódców świata. A także rosyjskie społeczeństwo. Czasem wyglądał na bezradnego (Попов, 1998, s. 190), a jednocześnie wydawał się politykiem, który od początku do końca kontroluje sytuację, jest „,carem samowładcą" - silnym i zdecydowanym przywódcą - zawsze przekonanym o słuszności swojego wyboru. Czy tak było w istocie? Jelcyn podejmował decyzje sam czy faktycznie robiło to jego otoczenie, najbliżsi współpracownicy, rodzina? Z pewnością był przekonany o tym, że rządzi samodzielnie. Czasem próbował to dobitnie okazać, dokonując zaskakujących roszad politycznych, wywyższając i dymisjonując swoich współpracowników - zwykle zresztą w sposób nieoczekiwany. Nerwowe ruchy kadrowe mogły wskazywać na to, że co pewien czas zauważał zbyt duży, jak sądził, wpływ otocznia na swoje prerogatywy, zwłaszcza po okresach niedyspozycji, kiedy to nie do końca kontrolował sytuację. Stale reagował, walczył, tworzył rozmaite przeciwwagi dla kremlowskich koterii. Nikt, dosłownie nikt, nie mógł być pewny „łaski” prezydenta. Niewątpliwie otaczał go pewien nimb władzy i siły, kontakty z nim mogły bowiem otworzyć drogę do kariery. Być może jednak były to tylko pozory, a o wszystkim decydowało otoczenie prezydenta, ludzie, którzy nauczyli się podejmować za niego decyzje, ale w taki sposób, by był on przekonany, że podejmuje je sam? Jelcyn miał do perfekcji opanowaną sztukę ,politycznego manewrowania”, ustawiania pozycji i figur. Kiedy osiagał cel, tj. przejmował całkowitą kontrolę nad sytuacją, wyciszał się. Unikał kłopotów i generalnie wszystkich sytuacji, które mogły go stresować: konferencji prasowych, wystappień publicznych, oficjalnych spotkań międzynarodowych, konfliktów we własnym otoczeniu oraz tych z opozycją. Taki stan zwykle trwał jednak bardzo krótko. Bez walki nie potrafił funkcjonować. Wielokrotnie sam prowokował konflikty, które zmuszały go do maksymalnego wysiłku. Kontakt z przeciwnikiem zdawał się jednak zwielokrotniać jego siły. Zepchnięty do narożnika, często sprawiał wrażenie słabego, wycofanego, nadużywał alkoholu, znikał na wiele dni. Niekorzystne sytuacje potrafił jednak obrócić na własną korzyść. Zawsze wracał i walczył. Igor Klamkin i Lilia Szewcowa twierdzili, że każdy, kto miał okazję spoglądać na Jelcyna z bliska, zauważał jego psychologiczną niezdolność do prowadzenia „,normalnej polityki” i ,absolutną skłonność do dzikiej walki" (Klyamkin, Shevtsova, 1999, s. 24). W chwili zagrożenia budził się w nim uśpiony potencjał działania. ,To człowiek zdolny tylko do rozwalania" stwierdził Gorbaczow w rozmowie ze swoim asystentem Grigorijem Szachnazarowem (Шахназаров, 2001, s. 376). Rosyjski psycholog Oleg Dawydow pisał, że skłonność Jelcyna do konfliktów była 
uwarunkowana niemal mistycznym przekonaniem o możliwości wyjścia bez szwanku z każdej sytuacji (Давыдов, 2000, s. 65-80). Rzeczywiście, prezydent wielokrotnie przywoływał w swoich książkach tę wiarę. ,,.. Zawsze było tak, jakby coś nade mną czuwało. W końcu sam zacząłem wierzyć, że pozostaję pod opieką jakiejś niepojętej siły. Żeby też jednemu człowiekowi stale przydarzyło się tyle różnych przygód, i to we wszystkich okresach życia. Dokładnie, we wszystkich. W dodatku każda taka krytyczna sytuacja stwarzała potencjalne śmiertelne zagrożenie" (Jelcyn, 1995, s. 306). Także Włodzimierz Marciniak zwrócił uwagę, że w życiu Jelcyna stale powtarzał się motyw ,śmiertelnego niebezpieczeństwa i cudownego uratowania" - systematycznie popadał on w niebezpieczne sytuacje, aby następnie z niezwykłym trudem z nich się wydostać (Marciniak, 2001, s. 165). Konflikty wyniszczały jednak Jelcyna psychicznie. Często chorował, nadużywał alkoholu. Dyskusje na temat jego skłonności do mocnych trunków stały się czymś zupełnie rutynowym wśród Rosjan i w dyspucie medialnej, podważały autorytet prezydenta. Czasami były to insynuacje puszczane w obieg przez jego przeciwników, często jednak ,niedyspozycje” miały charakter publiczny i oczywisty (Колтон, 2013, s. 281).

Dziś, z pewnej już perspektywy, można zadać szereg pytań dotyczących politycznej osobowości Jelcyna: czy wiele jego cech, decyzji i zachowań było spowodowanych wyłącznie osobliwościami charakteru czy może problemami, z którymi się zmagał: depresją, chorobami, prawdopodobną cyklotymią, alkoholizmem i zwykłymi kompleksami? Być może powiązanie tego aspektu ze sferą realnej polityki pozwoliłoby lepiej zrozumieć samego Jelcyna, ale przede wszystkim umożliwiłoby prawdziwe odczytanie podejmowanych przez niego decyzji i w konsekwencji - zrozumienie takiego, a nie innego modelu rozwoju postkomunistycznego państwa? Przyczyny niedyspozycji Jelcyna, to, czy były one wynikiem depresji, choroby serca, nadużywania alkoholu itd., są jednak kwestią drugorzędną. Ważne jest natomiast to, czy miały one wpływ na bieżące działanie i decyzje prezydenta, a także na kształt przeobrażeń w Rosji. O ile wpływ na bieżącą politykę jest raczej oczywisty i trudno go kwestionować - niewiadomą jest jednak jego skala o tyle cały system polityczny zaczął w pewnym momencie funkcjonować niezależnie od Jelcyna i jego słabości. Sama zmiana władzy na Kremlu w latach 1999-2000 pokazuje, że państwo i władza żyły już swoim odrębnym rytmem, na który prezydent być może nie miał większego wpływu. 


\section{System władzy Borysa Jelcyna}

Borys Jelcyn, mimo licznych słabości i problemów ze zdrowiem, do 1993/1994 roku umacniał swoją władzę, ale od 1995 roku już tylko stworzony przez siebie system. Oprócz prezydenta, w Rosji funkcjonowały rozmaite grupy interesu i ośrodki władzy: regiony, armia, media, parlament, lobby wydobywcze, przemysłowe, rolne, zbrojeniowe, dawna nomenklatura, byłe i obecne tajne służby, „oligarchowie” itd. Prezydent przez cały czas starał się, by interesy jego i tych grup pokrywały się. Nie było to do końca możliwe, bowiem oczekiwania poszczególnych lobby były w stosunku do siebie konfrontacyjne. Owe rozbieżności często kończyły się mniej lub bardziej otwartą walką angażującą instytucje państwa. Jelcyn umiał to wykorzystać - mógł występować jako arbiter - do pewnego stopnia sam zresztą kreował owe konflikty. Nie musiał jednak wszystkiego kontrolować, nie interweniował w zarządzanie w skali „mikro”. Robili to jego najbliżsi, wypełniając wolę zwierzchnika, często zresztą zgodnie z tym, jak rozumieli jego polecenia, a nie jak prezydent chciał faktycznie. To mu jednak wystarczało. Możliwość podejmowania decyzji, a po stronie współpracowników konieczność wypełniania jego zaleceń, nawet jeśli faktycznie bywał ,źle zrozumiany”, stanowiła wystarczający surogat władzy. Trudno przy tym założyć, że Jelcyn był jedynie figurantem, a prawdziwe decyzje podejmowano gdzie indziej. W kluczowych momentach podejmował decyzje samodzielnie - często wbrew opinii otaczających go frakcji. Rzecz jasna, mógł to być tylko pozór władzy, stworzenie mu przez otoczenie pewnych „korytarzy możliwości”, tj. sfer, w których mógł „carstwować”. Jelcyn miał bardzo ograniczone cele: rządzić, decydować, przetrwać, zwyciężyć, dlatego też wiele istotnych spraw, znajdujących się niejako na marginesie jego zainteresowań, mogło być faktycznie forsowane przez otoczenie prezydenta. Prawdopodobnie żył w przekonaniu, że zawsze sam podejmuje kluczowe decyzje, ale tak naprawdę mogły one zapadać niezależnie od jego woli.

To, czy Borys Jelcyn rzeczywiście rządził Rosją, czy też był w jakimś stopniu ubezwłasnowolniony, należy rozpatrywać w dwóch kontekstach: uwarunkowaniach polityczno-gospodarczych Rosji lat 90. oraz w relacjach prezydenta z najbliższym otoczeniem. Pozycja Borysa Jelcyna była pochodną systemu nieformalnych zależności w łonie nomenklatury, służb, grup interesu, a z czasem też „oligarchów”. Powiązania te powodowały, że prezydent mógł poruszać się jedynie w stosunkowo wąskim „korytarzu możliwości”. To, jak wyglądały rosyjskie reformy, wynikało w dużej mie- 
rze z możliwości, które czasem udawało mu się powiększać - po puczu Gienadija Janajewa doprowadził do rozwiązania ZSRR i przeforsowania pakietu reform Jegora Gajdara, po rozwiązaniu parlamentu w 1993 roku wprowadził reformę konstytucyjną. W obu wypadkach nie posunął się jednak na tyle daleko, by naruszyć interesy tych, z którymi musiał się liczyć. Jelcyn cały czas balansował między siłami, które próbowały opleść go siecią zależności czy wręcz ubezwłasnowolnić. Dość długo mu się to udawało. Potencjalnie miał wiele atutów. Wygrywał poparcie jednych przeciwko stanowisku innych. Stawał się przy tym istotnym elementem utrzymującym swoistą równowagę interesów. W drugiej połowie lat 90. doszło do sytuacji, w której prezydent, chociaż politycznie znacznie słabszy niż na początku swoich rządów, był bardziej potrzebny elitom - jako gwarant istniejącego status quo. System musiał mieć swojego lidera i dopiero pojawienie się realnej alternatywy - Władimira Putina zakończyło erę Jelcyna. Zbiegło się to z końcem drugiej kadencji prezydenta, dlatego też trudno powiedzieć, czy zmiana na Kremlu była efektem kompromisu elit, zwycięstwa jednej z grup (służb bezpieczeństwa) czy efektem samodzielnej decyzji Jelcyna, liczącego w zamian na parasol ochronny ze strony nowej władzy.

Drugi kontekst przywództwa Jelcyna to jego relacje z najbliższym otoczeniem. Tu sytuacja była mniej skomplikowana, a z pewnością nieco bardziej przejrzysta i zrozumiała z punktu widzenia obserwatorów rosyjskiej polityki. Wydaje się, że mimo chorób i niedyspozycji, Jelcyn niemal do samego końca, tj. jesieni 1999 roku, kontrolował sytuację. Nawet jeśli był zwodzony, okłamywany, często manipulowany, nawet jeśli czasem udawał bezradnego i wycofanego, to stale i konsekwentnie wyzwalał się spod wpływu, a niekiedy kurateli otoczenia. To była jego sfera „carstwowania”, nieograniczonej władzy. Mógł dymisjonować, wynosić na urzędy, nadawać i odbierać. Nie miało to zasadniczego wpływu na długofalową politykę państwa ${ }^{3}$, ale w sposób fundamentalny wpływało na kariery i majątki poszczególnych osób. Rosyjska polityka lat 90. w dużym stopniu była więc walką o dostęp do prezydenta i wyeliminowanie ewentualnej konkurencji. Była to gra o tyle niebezpieczna, że Jelcyn bezwzględnie ${ }^{4}$ niszczył każdego, kto potencjalnie czy faktycznie chciałby uzyskać zbyt duże wpływy. Słabym elementem tego systemu była córka

3 Może poza wylansowaniem Władimira Putina.

4 Przy czym owa „bezwzględność” polegała na odsunięciu od władzy i wpływów, a nie, jak ma to miejsce w czasach Putina, na zmuszeniu do emigracji, odbieraniu majątków, zesłań do obozów pracy czy nawet fizycznym eliminowaniu przeciwników. 
prezydenta - Tatiana Diaczeko - której Jelcyn ufał, a która nie potrafiła zdystansować się od walczących o władzę na Kremlu koterii. To ona sprawiała, że prezydent stawał się coraz bardziej zależny od jednej frakcji - „familii”.

Klucz do zrozumienia polityki Jelcyna może jednak wydawać się dość kontrowersyjny. Wbrew obiegowej opinii, postrzegania go jako awanturnika i człowieka dążącego do konfliktów (co w pewnym stopniu odpowiadało prawdzie), prezydent za wszelką cenę poszukiwał właśnie spokoju i stabilizacji, ale rozumianych jako brak politycznej konkurencji. Unikał konfrontacji, negocjował, zawierał kompromisy, poświęcał bliskich, „udawał, że go nie ma" (Jelcyn udawat, 2002). Decydował się na konflikt dopiero wtedy, kiedy nie miał innego wyjścia i był - w subiektywnej ocenie - ,przyparty do muru”. Nie ulegał przy tym groźbom - to wywoływało w nim efekt wprost przeciwny: naturalną skłonność do walki.

\section{Dziedzictwo Borysa Jelcyna}

Analizując rządy Jelcyna, trzeba pamiętać, w jakich warunkach przyszło mu sprawować władzę. Na początku lat 90 . kraj był na progu gospodarczej katastrofy - zdewastowany okresem komunizmu, zacofany technologicznie i infrastrukturalne, nieprzygotowany na wolność, demokrację, wolny rynek. Rosji groził rozpad. Państwo traciło swoje atuty w polityce międzynarodowej, miało przerośniętą ponad stan i możliwości armię, z którą nie bardzo było wiadomo, co zrobić. Nie wszyscy Rosjanie zgadzali się też z przyjętym modelem reform, wielu tęskniło za Związkiem Radzieckim i jego systemem zabezpieczeń socjalnych. Jelcyn musiał nie tylko budować od podstaw, ale też walczyć z tym, co zastał: mentalnością, przyzwyczajeniami, układami. Bardzo szybko okazało się, że jego pole manewru jest bardzo ograniczone - podejmując jakieś działania, natrafiał na opór różnych lobby, społeczeństwa, opozycji, a nawet własnego otoczenia. Już w 1992 roku zaczął tracić możliwość swobodnego kreowania rzeczywistości.

Jego polityka przerodziła się w doraźne reagowanie na kolejne problemy i zagrożenia. Mimo to próbował, szukał rozwiązań - bez skutku. Miotał się od skrajności do skrajności - rząd Gajdara przyniósł dramatyczną pauperyzację i rozwarstwienie społeczeństwa oraz wojnę domową z parlamentem, rząd Czernomyrdina spowodował pewne wyciszenie konfliktów politycznych, ale też stagnację i oligarchizację 
kraju. Kolejny premier - Kirijenko to dramatyczny kryzys finansowy i ponowna klęska prezydenta. Jelcyn znalazł się trochę w sytuacji Gorbaczowa: wszystko, co robił, obracało się przeciwko niemu, wszystko było krytykowane i kontestowane, faktycznie też niewiele mu się udawało. Był zresztą bardziej zainteresowany utrzymaniem i umocnieniem swojej władzy, nawet siłą, niż reformami. Ostatecznie sprawy toczyły się niejako swoim rytmem, a Kreml zdawał się nie pomagać, a wręcz szkodził Rosji.

Bilans rządów Jelcyna nie układał się jednak w oczywisty schemat. Jego ocenę w dużym stopniu determinuje fakt, że działał on w specyficznych warunkach odziedziczonego po poprzednikach kryzysu ekonomicznego, ustrojowego i społecznego. Często okoliczności te wymuszały określone decyzje, których dzisiejsza ocena może być niesprawiedliwa. Posunięcia Jelcyna zwykle były próbą gaszenia pożaru trawiącego Rosję od wielu lat, jeśli nie dziesięcioleci. Prezydent nie miał czarodziejskiej różdżki, którą mógłby w jednej chwili odmienić rzeczywistość - a wielu, jak się wydaje, na to liczyło. Inna rzecz, że w drodze po władzę, Jelcyn przekonywał, że do szczęścia i dobrobytu wystarczy tak niewiele: rozwiązanie ZSRR, pozbycie się Gorbaczowa, kilka reform rynkowych. Miał jednak swoje niekwestionowane sukcesy, przede wszystkim zburzył podstawy systemu totalitarnego (chociaż można zastanawiać się, czy równie wielki, o ile nie większy, wpływ na upadek komunizmu w Rosji miał Gorbaczow i grupa jego liberalnych współpracowników), zapoczątkował przekształcenia własnościowe w państwie i pełną liberalizację życia politycznego. Umocnił wolność słowa, stworzył sektor prywatny, pomógł uzyskać niepodległość krajom poradzieckim, doprowadził do znacznego odkłamania historii, zgodził się na wielkie przemiany geopolityczne w Europie Środkowej - był gwarantem nieodwracalności upadku komunizmu. Udało mu się zachować integralność państwa i na tyle odbudować jego wewnętrzną siłę, że skok do odrodzenia się mocarstwowości Rosji (za czasów prezydentury Putina) nie był wcale aż taki trudny. Za jego rządów Rosja zaczęła być postrzegana na arenie międzynarodowej jako partner, a nie przeciwnik. To Jelcyn wysunął koncepcję suwerenności Rosji, a jednocześnie bronił prawa innych narodów radzieckich do samostanowienia. Na przełomie lat 80 . i 90 . trzeba było mieć sporo odwagi, aby powiedzieć: „Bierzcie tyle suwerenności, ile jesteście w stanie udźwignąć", a także by - przeciwstawiając się Kremlowi - poprzeć walczących o niepodległość Bałtów i wezwać żołnierzy radzieckich, aby nie strzelali do litewskich patriotów. 
Z perspektywy widać jednak, że Jelcyn nie wykorzystał w pełni swej historycznej szansy, nie potrafił do końca unieść roli, którą dały mu okoliczności, nie zaszczepił w Rosji autentycznej liberalnej demokracji. Nie pomógł rozwojowi społeczeństwa obywatelskiego. Co gorsza, spowodował, że Rosjanie zatęsknili za silną władzą, która gwarantowałaby im stabilizację, a państwu porządek. Konsekwencją owych oczekiwań stało się społeczne przyzwolenie na autorytarne rządy Putina. Rosja, zrywając $\mathrm{z}$ totalitaryzmem, nigdy nie stała się państwem demokratycznym (Шевцова, 2004). Na kilka lat „zawisła” między systemami, nie potrafiąc określić ani drogi rozwoju, ani rzeczywistych potrzeb. Tworzący zalążek rosyjskiej demokracji nie rozumieli, że system ten wymaga silnych instytucji politycznych, opozycji - twardej w stosunku do rządzących - ale jednocześnie lojalnej wobec państwa, licznej i świadomej swego znaczenia klasy średniej, umiejętności i woli osiagania kompromisu, respektowania celów mniejszości. Demokrację sprowadzono do procedury - regularnych wyborów, które stały się politycznym i prawnym alibi dla totalnego zawłaszczania państwa i władzy. Demokracja zaczęła być postrzegana przez rządzących zwycięzców jako uprawomocnienie podziału łupów. Ta skrajnie zawężona interpretacja wzbudziła, w pierwszym rzędzie, zniechęcenie społeczeństwa. Nie rozumiało ono dlaczego dla tego typu wartości demokratycznych, ma poświęcać stabilizację i socjalne bezpieczeństwo, które niegdyś gwarantował Związek Radziecki. Bezpieczeństwo było postrzegane jako wartość ważniejsza niż kilka oczywistych wad dawnego systemu, takich jak brak wolności słowa, niemożność podróżowania po świecie, zakaz kontaktu z obcymi czy administracyjne ograniczenia związane z życiem codziennym. Demokracja w tym kontekście nie była priorytetem. Wolność słowa, pluralizm itd. w warunkach problemów bytowych pozostawał kwestią najwyżej drugorzędną. Nieufność wobec demokracji dodatkowo wzmacniał fakt, że polityka liberalizacji i wartości, które jej towarzyszyły, stała się zwyczajnie uciążliwa. Indywidualizm i wolna przedsiębiorczość uderzały w utrwalone kulturowo wartości kolektywizmu i egalitaryzmu.

Wielką przegraną Jelcyna było odcięcie się od społeczeństwa - od jego bólu i strachu (Gessen, 2012, s. 18), a także faktyczne wyłączenie go z życia politycznego oraz swoista petryfikacja mentalności, zachowań i oczekiwań z poprzedniej epoki. O ile Gorbaczow przygotował Rosjan do jakiejś formy demokracji, o tyle Jelcyn podłożył podwaliny pod autorytaryzm. Rządzący Rosją wielokrotnie zmieniali oficjalną ideologię państwa, co wynikała zarówno z próżni ideologicznej, powstałej po roz- 
padzie ZSRR, jak i ze stale zmieniających się warunków społeczno-politycznych, a także międzynarodowych. Ciągłe zmiany w tym zakresie musiały potęgować dezorientację obywateli, wskazywać na intelektualny kryzys władzy i jej ideologiczną niestabilność. Było to szczególnie niebezpieczne w kraju, którego obywatele wychowani byli w duchu ideologicznej wszechmocy państwa. Trudno przy tym nie zauważyć antynomii ujawniającej się między długo lansowanym przez reżim zachodnim modelem rozwoju państwa a rzeczywistymi konsekwencjami takiej modernizacji. Ta nie przyniosła głębszego rozwoju indywidualizmu, racjonalizmu czy umocnienia liberalnych wartości i instytucji. Pomimo prowadzenia reform pod takimi auspicjami, okazało się, że społeczeństwo jest nadal kolektywne. Zamiast normalnej, kapitalistycznej gospodarki, opartej na zasadach konkurencji i wolnego rynku, pojawił się kryminalny kapitalizm, zamiast demokratycznych instytucji społeczeństwa obywatelskiego - „klany”, „kasty”, systemy wasalizmu i klientelizmu. Niedoszłe społeczeństwo obywatelskie rozpadło się na kryminalną i półkryminalną elitę, z jednej strony, oraz masy „upośledzonych”, z drugiej (Кулинченко, Кулинченко, 2003, s. 151). Rządzący nie byli zainteresowani tym, by w szerszym zakresie stymulować rozwój instytucji społecznych. Umiejętność balansowania pomiędzy tendencjami autorytarnymi a oczekiwaniami narodu stała się więc podstawowym zadaniem władzy politycznej. Problem ten, przynajmniej do pewnego stopnia, był zrozumiały dla Jelcyna. Nie jest to dziwne, zważywszy, że doszedł on do władzy jako trybun ludowy. Do końca swojej prezydentury pozostawał jednak wyczulony na zmieniające się nastroje społeczne, rozumiał je nawet wtedy, kiedy ich nie akceptował. Tej umiejętności nie posiadł chyba jego następca. Założył on, że naród powinien identyfikować się ze swoim prezydentem, dawać mu swoje poparcie w imię wspólnych celów i ambicji. Problem w tym, że cele władzy i społeczeństwa często bywały przeciwstawne, obie strony inaczej je też pojmowały.

Rosjanie nie zapamiętali pozytywnych dokonań swojego prezydenta: odbudowania i przetrwania suwerennej Rosji, pogłębienia zapoczątkowanych przez Gorbaczowa przemian społeczno-politycznych i gospodarczych, zachowania względnego pokoju na obszarze postradzieckim, zbudowania fundamentów prywatnej własności, nawiązania dobrych, niekiedy wręcz przyjacielskich, stosunków z Zachodem i Chinami czy też tego, że dał Rosji impuls do zmian i potencjalnego rozwoju. Po latach pamiętają go raczej jako przywódcę, który przyczynił się do kryzysu państwa - nowej ,wielkiej smuty”, oznaczającej upadek światowego mocar- 
stwa, ,złodziejskiej prywatyzacji”, biedy, politycznej anarchii, ofiar wojny w Czeczenii, korupcji, nepotyzmu i oligarchizacji państwa. Łatwo to zrozumieć. Dekada lat 90. odebrała Rosjanom optymizm i entuzjazm do reform, rynku, demokracji, zmusiła ich do zajęcia się swoimi sprawami bytowymi, pozbawiła wiary w to, że człowiek może pozytywnie kształtować swój los. Wielkie emocje i nadzieje, które towarzyszyły społeczeństwu w latach 1990-1993 zostały zaprzepaszczone - w dużym stopniu właśnie przez błędy Jelcyna. Pojęcia takie, jak: „pluralizm”, „,demokracja parlamentarna”, „otwartość” czy „wolny rynek” wryły się w rosyjską świadomość jako najgorsze epitety. Zamiast systemu demokratycznego Jelcyn zbudował podwaliny pod quasi-autorytaryzm, wykorzystany przez jego następcę. Zamiast wolnego rynku - biurokratyczno-klanowe korporacje, zamiast ostatecznie wyzwolić aktywność Rosjan - spowodował powrót zastraszonej, inercyjnej i „skorumpowanej”5 masy. Dimitrij Łyskow w 2011 roku na łamach „Prawdy” pisał, że w masowej pamięci Rosjan Jelcyn pozostał symbolem per se. W jego zakresie zawierały się: „niezależność” od własnych historycznych terytoriów, pełna zależność polityki wewnętrznej od grup „oligarchów”, upokorzenie Rosji przez politykę zagraniczną Andrieja Kozyriewa, swoboda słowa, która przekształciła się w wojnę informacyjną i chaos przykryty tracącymi znaczenie terminami „,demokracja” i „reformy rynkowe”. Jelcyn zniszczył komunistyczną nomenklaturę w „czarnych wołgach”, stworzył za to nową, ale jeżdżącą mercedesami (Лысков, 2011). Już na podstawie tej opinii widać, że oceny byłego prezydenta Rosji mogą być skrajne, przepełnione wciąż świeżymi emocjami, wspomnieniem chaosu, swoistej nieokreśloności systemu i państwa, osobistymi dramatami. Na świecie Jelcyn został głównie zapamiętany jako ten, który doprowadził do likwidacji ZSRR. Dla większości mieszkańców byłego Związku Radzieckiego komunistyczne państwo było jednak ojczyzną, rozpad ZSRR na niezależne państwa traktowali jak jej upadek, a odpowiedzialnym za tę tragedię był właśnie Borys Jelcyn.

\section{Podsumowanie}

Jelcynowi nigdy nie udało się osiągnąć takiej władzy, jaką mieli przywódcy KPZR czy nawet jego następca - Władimir Putin. Dwukrot-

5 „Skorumpowanej” w sensie przyzwolenia na rządy niedemokratyczne w zamian za utrzymanie przywilejów socjalnych. 
nie zbliżał się do dyktatury (jesienią 1991 i 1993 roku), ale nie chciał, nie potrafił lub nie mógł umocnić swojego monowładztwa. Decydujące znaczenie miała tu nieudana i zapewne niemożliwa do zrealizowania próba połączenia rozwiązań demokratycznych z prezydenckim quasiautorytaryzmem. Jelcyn chciał być demokrata, reformatorem, przywódcą kochanym przez naród i docenianym przez polityków Zachodu, a jednocześnie władca, który całkowicie kontroluje życie polityczne. Paradoksalnie prawdziwym przywódcą był wtedy, kiedy wcielał się w rolę demokraty. Rola ta była jednak nie do utrzymania, ponieważ musiała skutkować ograniczeniem, a potencjalnie nawet utratą władzy - to zaś nie wchodziło w rachubę. W tym zakresie charakter i oczekiwania Jelcyna bezpośrednio wpływały na perturbacje systemu politycznego. W drugim okresie swoich rządów, tj. w latach 1996-1999, prezydent coraz bardziej oddalał się od swojej „demokratycznej” tożsamości. Ostatecznie pękł sojusz Kremla z „ulicą”, sam Jelcyn zatracił też umiejętność komunikowania się ze społeczeństwem. Postawił na elity. Stworzenie nowego, postkomunistycznego konsensusu elit i grup interesu, kontrolowanego przez sprawne polityczne centrum, wymagało czasu, środków, stabilizacji, siły i woli. Jelcyn budował swój system w warunkach fatalnych - w rozpadającym się świecie sowieckim, głębokiej zapaści gospodarczej i permanentnym kryzysie konstutucyjno-prawnym (do jesieni 1993 roku), czując presję sił, których się obawiał: biurokracji, regionów, nomenklatury, służb, armii, postsowieckich lobby ekonomicznych, a których znaczenie i siłę chyba jednak nieco przeceniał. Od początku zmuszony do lawirowania, kompromisów, czasem otwartej walki, podjął krótkotrwałą próbę reformy państwa, ale w obliczu narastającej presji - spasował. Od 1994 roku Rosja wpadła w stagnację. Jelcyn nie był w stanie przełamać impasu, ponieważ jakakolwiek głębsza reforma wymagała naruszenia pozycji grup interesu. Była to prawdziwa pułapka uwarunkowań. Prezydent zmuszony był do szeregu ustępstw na rzecz regionów, armii, postsowieckich lobby gospodarczych czy „oligarchów”. Nie mógł rządzić bez uwzględnienia ich postulatów. Miało to zresztą swój wymiar praktyczny: każda licząca się siła, posiadała $\mathrm{z}$ reguły swoją reprezentację w rządzie, a więc bezpośrednią kontrolę realizacji swoich oczekiwań. Prezydent dobitnie przekonał się o tym pod koniec 1992 roku i wiosną 1998 roku, kiedy okazało się, że rząd nie jest w stanie prowadzić sprawnej polityki ekonomicznej bez porozumienia z postsowieckimi lobby gospodarczymi (1992 rok) czy „oligarchami” (1998 rok). Funkcjonując w stosunkowo wąskim „korytarzu możliwo- 
ści”, Jelcyn konsekwentnie umacniał jednak sam system władzy. Prezydent stawał się punktem odniesienia dla elit, arbitrem, szafarzem dóbr i przywilejów, gwarantem bezpieczeństwa, równowagi i barierą przed postkomunistyczną recydywą. Proces ten miał poniekąd charakter naturalny: wszystkim zależało na stabilizacji, a tę najłatwiej było osiągnąć w warunkach względnego monowładztwa Kremla. Względnego, ponieważ dominacja bezwzględna musiała prowadzić do ograniczenia przywilejów i bezpieczeństwa elit. Prezydent miał być na tyle silny, by utrzymać i kontrolować istniejące status quo i jednocześnie na tyle słaby, by nie mógł rozszerzyć swojej władzy na sfery pozostające pod kontrolą różnych grup interesu. W pozostawionym mu ,korytarzu możliwości”, który okresowo rozszerzał się lub zawężał, Jelcyn mógł prowadzić niezależną politykę, a nawet odgrywać rolę „cara”. Stopniowo umacniał przy tym tendencje, które stały się podstawą prezydenckiego autorytaryzmu po 1999 roku. To Jelcyn doprowadził do ograniczenia roli opozycji, zdepolityzował społeczeństwo, ubezwłasnowolnił i skorumpował elity, zmonopolizował obieg informacji, stworzył system klientelistycznej zależności elit i społeczeństwa od władzy, zalegalizował bezkarność - system, w którym władza mogła praktycznie wszystko. Putin otrzymał w spadku ukształtowany fundament władzy, którego jedyną poważną słabością był brak silnego lidera. Jelcyn nie mógł zbudować quasi-dyktartury. Nawet jeśli chciałby to zrobić, funkcjonował w systemie, który ograniczał i krępował jego posunięcia. Pod koniec dekady jego możliwości potencjalnie były znacznie większe, jednak on sam nie był już w stanie po nie sięgnąć. Problemem mógł być tu stan zdrowia, ale ważniejsze było to, że elity w sposób naturalny zaczęły już poszukiwać nowego przywódcy. System potrzebował nowego lidera. Był przygotowany na nowe rozdanie. Gdyby nie pojawił się Władimir Putin, ster władzy przechwyciłby Primakow lub Łużkow. Zmieniłoby to prawdopodobnie akcenty rosyjskiego autorytaryzmu - decydująca siłą byłaby biurokracja i lobby gospodarcze, a nie służby - ale nie jego istotę. O tym, kto będzie rządził Rosją, ostatecznie nie zadecydowały jednak grupy interesu, kremlowskie koterie czy społeczeństwo - była to raczej samodzielna decyzja Jelcyna, który wybrał jedną z możliwych opcji. Z pewnością miał on niewielkie pole manewru. W 1999 roku poruszał się w skrajnie zawężonym „korytarzu możliwości”. To, że jego wola została zaakceptowana przez elity i potwierdzona w wyborach, może jednak świadczyć o tym, że niemal do końca, przynajmniej w jakimś stopniu, kontrolował stworzony przez siebie system. 


\section{Bibliografia}

Darczewska J. (2000), Zburzył komunizm, przegrał demokrację, „Polityka” nr 3.

Давыдов О. (2000), Ельцинская трехходовка, w: Российская элита: психологические портреть, pod red. А. Н. Старкова, Ладомир, Moscow.

Gessen M. (2012), Putin. Człowiek bez twarzy, thum. J. Szajkowska, M. Witkowska, Prószyński i S-ka.

Jelcyn B. (1995), Notatki prezydenta, thum. z ros. A. Kotowska, Warszawa.

Jelcyn udawat, że go nie ma Putin udaje, że jest (2002), Rozmowa z Borysem Bieriezowskim, http://basajew.blog.pl/2002/12/29/ jelcyn-udawal-ze-go-nie-maputin-udaje-ze-jest.

Klyamkin I., Shevtsova L. (1999), This Omnipotent and Impotent Government: The Evolution of the Political System in Post-Communist Russia, Moscow.

Колтон Т. (2013), Ельцин, Москва.

Кулинченко В. А., Кулинченко А. В. (2003), О духовно-культурныхх основаниях модернизаиии России, „Polis” nr 2.

Лысков Д. (2011), 80-летие Ельцина: суд истории вершим мы,, „Правда.Ру” $\mathrm{z}$ dnia 1.02.2011.

Marciniak W. (2001), Rozgrabione imperium. Upadek Zwiqzku Sowieckiego i powstanie Federacji Rosyjskiej, Kraków.

Попов Г. (1998), Будет ли у России второе тысячелетие, Москва.

Popowski S. (1996), Wiele twarzy Borysa Jelcyna, „Rzeczpospolita” nr 138, z dnia 15.11.1996.

Прибыловский В. (2009), У Ельцина не было убеждений - только идея власти, „Свободная Пресса” z dnia 31.12.2009.

Remnick D. (1997), Zmartwychwstanie..., thum. z ros. M. Słysz, Warszawa.

Шахназаров Г. (2001), С вождями и без них, ВАГРИУС, Москва.

Шевцова Л. (2004), Демократия: логика вырождения, „Ведомости” z dnia 26.01.2004.

Третьяков В. (2000), Свердловский выскочка, „Независимая газета” z dnia 6.01.2000.

\section{Boris Yeltsin as a political leader}

\section{Summary}

Boris Yeltsin successfully led to the fall of the USSR and the monopolization of power. However, he was not mentally prepared to be the leader of the nation during the transformation in the 1990s. He did not attempt to consolidate the state, but rather to build his own leadership. The power system he had created became the foundation 
upon which the authoritarian regime of Vladimir Putin was formed. It was Yeltsin who taught the Russian elite how to bend and even dodge democratic procedures, how to dismiss and marginalize the opposition, appropriate mass media and corrupt journalists; how to incapacitate politicians and intelligentsia; how to push society away from influencing political life; how to disintegrate and disregard political life. All these factors triggered a social longing for stability and the rule of a "strong hand." Yeltsin discouraged Russians from democracy and the free market, allowed the emergence of Russian "oligarchism," restored Russia's old perception of international reality, and legalized state violence. In fact, it was not about ideology, but about the people who stood in his way. Many elements of the Soviet state were intentionally adopted by Yeltsin. In this way, a specific transposition of communism took place. Its imperial, social and political power was adapted to the idea of new Russia. Yeltsin undoubtedly contributed to the creation of independent Russia, but the whole sphere of freedom was only an active development of the changes initiated by Mikhail Gorbachev.

Key words: Russia, Yeltsin, Communism, democratization, post-Communism 